\title{
MODEL REGRESI COX UNTUK MENGANALISIS PENGARUH FAKTOR ASUPAN MAKANAN TERHADAP RISIKO KEKAMBUHAN ENDOMETRIOSIS
}

\section{Cox Regression Model to Analyse the Effect of Food Intake on Endometriosis Recurrence}

\author{
Ning Eliyati ${ }^{1}$, Sri Indra Maiyanti ${ }^{2 *}$, Oki Dwipurwani ${ }^{3}$, Shaly Wanda Hamidah ${ }^{4}$ \\ 1,2 Jurusan Matematika, FMIPA, Universitas Sriwijaya \\ Jln. Raya Prabumulih Inderalaya Ogan Ilir, Sumatera Selatan, 30662, Indonesia
}

Corresponding author e-mail: 2*yanti_sri02@yahoo.com

\begin{abstract}
Abstrak
Tujuan penelitian ini adalah untuk menganalis hubungan faktor asupan makanan (buah, kedelai, susu, kafein, daging merah, bawang putih, jahe, seafood, keju, teh hijau, beras merah, gandum, kentang, tauge, sawi, minuman bersoda dan alkohol) terhadap risiko kekambuhan endometriosis, dengan model hazard proporsional Cox metode backward. Waktu survival adalah waktu sejak operasi pertama sampai terjadi kekambuhan. Hasil analisis menunjukkan faktor asupan makanan yang signifikan menurunkan risiko kekambuhan dengan $p$-value masingmasing adalah konsumsi buah 1-4 (0,01) dan 5-7 kali/minggu (0,08), sawi 1-7 (0,006), tauge 3-7 (0,007) dan seafood 3-7 kali/minggu (0,0). Faktor yang meningkatkan risiko kekambuhan endometriosis adalah konsumsi susu 3-4 (0,004), seafood 1-2 (0,00), kedelai 1-2 (0,002) dan kedelai 3-7 kali/minggu $(0,001)$. Konsumsi kedelai 1-2 dan 3-7 kali/minggu, kemungkinan kambuh 30,3 dan 43,9 kali dibandingkan konsumsi kedelai <1 kali/minggu adjusted terhadap faktor lain. Konsumsi susu 3-4 kali/minggu berisiko kambuh 24 kali dibandingkan yang konsumsi susu $<1 \mathrm{kali} /$ minggu.
\end{abstract}

Kata Kunci : Asupan Makanan, Endometriosis, Hazard Rasio, Kekambuhan Endometriosis, Regresi Cox.

\begin{abstract}
This research purpose is to analyze the relationship between food intake factors (fruit, soy, milk, caffeine, red meat, garlic, ginger, seafood, cheese, green tea, brown rice, wheat, potatoes, bean sprouts, mustard greens, soft drinks and alcohol) on hazard of endometriosis recurrence, using the Cox proportional hazard model backward method. The results of the food intake factors that significantly reduced the risk of endometriosis recurrence are fruit 1-4 times/week ( $p$-value 0.01), fruit 5-7 1-4 times/week ( $p$-value 0.08), mustard greens 1-7 times/week ( $p$ value 0.006), bean sprouts 3-7 (p-value 0.007) and seafood times/week. Factors that increase the risk of endometriosis recurrence are consumption of milk 3-4 times/week ( $p$-value 0.004), seafood 1-2 times ( $p$-value 0.00), soy 1-2 times/week (p-value 0.002), and 3-7 times/week (p-value 0.001). Soy consumption 1-2 and 3-7 times/week are likely to relapse 30.3 and 43.9 times compared to soy consumption $<1$ times/week. Consumption of milk 3-4 times/week has a risk of relapse 24 times compared to consume milk <1 times/week.
\end{abstract}

Keywords: Cox Regression, Endometriosis, Food Intake, Hazard Ratio, Recurrence of Endometriosis.

Article info:

Received: $09^{\text {th }}$ December 2020

Accepted: $25^{\text {th }}$ February 2020

How to cite this article:

N. Eliyati, S. I. Maiyanti, O. Dwipurwani, S. W. Hamidah, "MODEL REGRESI COX UNTUK MENGANALISIS PENGARUH FAKTOR ASUPAN MAKANAN TERHADAP RISIKO KEKAMBUHAN ENDOMETRIOSIS”, BAREKENG. J. Il. Mat. \& Ter., vol. 15, no. 1, pp. 103114, Mar. 2021.

This work is licensed under a Creative Commons Attribution-ShareAlike 4.0 International License.

Copyright ${ }^{\circ} 2021$ Ning Eliyati, Sri Indra Maiyanti, Oki Dwipurwani, Shaly Wanda Hamidah 


\section{PENDAHULUAN}

Endometriosis didefinisikan sebagai adanya jaringan seperti endometrium, yang biasanya tumbuh dalam dinding rahim, jadi tumbuh diluar rahim atau di rongga panggul. Endometriosis dapat tumbuh di sekitar organ reproduksi wanita ataupun didalam rongga panggul seperti di dipermukaan rahim, saluran telur, indung telur, kavum douglas, rectum, kandung kemih dan usus. Endometriosis menyebabkan berbagai gejala nyeri kronis dan infertilitas [1].

Pengobatan untuk endometriosis tergantung tingkat keparahan gejalanya dan keinginan untuk punya anak. Pengobatan endometriosis meliputi pemberian obat anti inflamasi, terapi hormon dan terapi pembedahan. Pengobatan endometriosis bertujuan untuk mengurangi gejala nyeri, memperlambat pertumbuhan lesi endometriosis dan meningkatkan kesuburan supaya bisa hamil dan punya keturunan [1][2].

Sampai saat ini, pengobatan medis belum mampu dengan tuntas meniadakan penyakit ini. Kekambuhan nyeri, infertilitas dan lesi endometriosis setelah pembedahan masih sering terjadi, bahkan beberapa pasien memerlukan operasi ulang. Walaupun pembedahan telah digabungkan dengan pemberian obat-obatan ataupun terapi hormon, kekambuhan tetap terjadi [3]. Selain menyebabkan nyeri kronis dan infertilitas, endometriosis juga berdampak tidak baik pada fisik, psikis, pekerjaan, hubungan dengan pasangan dan juga pada ekonomi keluarga karena biaya pengobatan yang mahal [4]. Endometriosis juga berdampak pada kualitas hidup, kecemasan dan depresi [5]. Sehingga diperlukan alternatif usaha lain dalam menanggulangi penyakit ini, selain dari sisi medis, misalnya dari faktor asupan makanan, yaitu mengatur diet dan nutrisi (mengkonsumsi makanan dapat menurunkan risiko kekambuhan dan menghindarkan makanan yang meningkatkan risiko kekambuhan).

Konsumsi makanan tertentu diduga dapat menaikkan atau menurunkan risiko kekambuhan endometriosis [6][7]. Makanan yang dianjurkan untuk penderita endometriosis adalah makanan tinggi serat (sayuran dan buah-buahan), kaya zat besi, asam lemak omega 3 dan tinggi anti oksidan. Sedangkan makanan yang harus dihindari adalah yang mengandung alkohol, kafein (kopi, teh, coklat), gluten, lemak trans, susu dan olahan susu, dan daging merah [8]. Pendapat lain mengatakan makanan yang dianjurkan untuk penderita endometriosis adalah makanan untuk keseimbangan hormon (kacang-kacangan, arbei, apel, buncis), makanan yang bermanfaat pada sistem imunitas (bawang, nanas, wortel, susu masam kental, teh hijau, jahe, bawang putih, cabe rawit), suplemen vitamin dan mineral (vitamin A, C, E, magnesiun, zink, kalsium, besi). Sementara makanan yang harus dihindari adalah gandum atau makanan yang mengandung gluten (roti / kue), alkohol, coklat, gorengan, gula, keju, susu, mentega, kafein (pada kopi, teh, minuman ringan) [9].

Beberapa penelitian telah meneliti hubungan diet dan risiko endometriosis. Hasil penelitian memberikan hasil yang sama atau kontras. Penelitian [6], menyimpulkan bahwa peningkatan konsumsi lemak total dan susu dikaitkan dengan penurunan risiko endometriosis, peningkatan konsumsi $\beta$-karoten dan porsi buah per hari dikaitkan dengan peningkatan risiko. Wanita dengan endometriosis tampaknya lebih sedikit mengonsumsi sayuran dan asam lemak tak jenuh ganda omega-3 dan lebih banyak konsumsi daging merah, kopi, dan lemak trans [10]. Asupan sayuran hijau dan buah segar yang lebih tinggi dikaitkan dengan penurunan risiko endometriosis sementara asupan daging merah meningkatkan risiko [11]. Penelitian [12] menyimpulkan bahwa konsumsi daging merah meningkatkan endometriosis. Asupan buah yang lebih tinggi, terutama buah jeruk, dikaitkan dengan risiko endometriosis yang lebih rendah, demikian juga dengan asupan beta-cryptoxanthin, tidak terlihat hubungan antara total asupan sayuran dengan penurunan risiko endometriosis [13]. Wanita dengan asupan protein yang lebih tinggi, terutama protein hewani, asam lemak tak jenuh tunggal, serat larut dan tidak larut, asam oleat, asam eicosapentaenoic, dan asam docosahexaenoic endometriosis lebih jarang terjadi ( $\mathrm{p}<0,05$ ), kemudian konsumsi tinggi sayuran, buah-buahan, daging merah, sayuran kuning, kentang, kacang-kacangan, produk susu, minyak cair, dan asupan kentang goreng yang rendah dikaitkan dengan risiko endometriosis yang lebih rendah $(p<0,05)$ [14]. Asupan fitoestrogen total yang tinggi dalam makanan terkait dengan penurunan risiko endometriosis, tapi fitoestrogen dalam susu dan coumestrol dalam buah-buahan berpengaruh negative terhadap risiko endometriosis [15]. Penelitian pengaruh efek aktioksidan dari supplemen kurkumin untuk mengurangi jumlah radikal bebas yang beredar dalam darah yang selanjutnya diharapkan dapat mengurangi kadar MDA yang tinggi pada penderita endometriosis, dilakukan oleh Puspitasari [16], hasil penelitian tersebut, yang dilakukan selama tiga bulan, dapat menurunkan rata-rata kadar MDA, walapun tidak bermakna secara statistik. Sementara penelitian Mvondo et. al. [17] menyimpulkan bahwa konsumsi kedelai secara teratur dapat meningkatkan perkembangan endometriosis di masa dewasa, terutama ketika kandungan kedelai dalam makanan lebih dari $10 \%$. 
Pada penelitian tentang pengaruh makanan dan risiko endometriosis yang telah dibicarakan sebelumnya [6][10][11][13], meneliti hubungan makanan dengan endometriosis pada pasien endometriosis terhadap pasien yang sehat (bukan endometriosis) atau penelitian kasus control (case control), bukan terhadap kekambuhan endometriosis setelah operasi. Pada penelitian ini dianalisis hubungan faktor asupan beberapa makanan yaitu konsumsi buah, kedelai, susu, kafein, daging merah, bawang putih, jahe, seafood, keju, teh hijau, beras merah, gandum, kentang, tauge, sawi, minuman bersoda, mentega, dan alkohol terhadap hazard kekambuhan endometriosis setelah operasi pertama kali.

Waktu sejak operasi pertama kali sebagai waktu awal (origin time) sampai terjadinya kekambuhan endometriosis sebagai waktu akhir (end point) dalam Statistika dikenal sebagai waktu survival (survival time) dan analisis yang digunakan dikenal dengan analisis survival (Survival Analysis). Salah satu tujuan analisis survival adalah menganalisis hubungan variabel-variabel penjelas (faktor resiko) dengan outcome (waktu survival) dan model yang populer dan untuk itu adalah model hazard proporsional Cox (Cox proportional hazards model) atau model regresi Cox[18]. Model hazard proporsional Cox merupakan model yang popular karena walaupun baseline hazard pada model tidak spesifik atau mengikuti distribusi tertentu tapi tetap menghasilkan nilai dugaan koefisien, rasio hazard dan kurva survival adjusted yang baik atau model hazard proporsional Cox merupakam model yang "robust" [19].

Pada penelitian ini dianalisis hubungan atau pengaruh faktor asupan makanan terhadap waktu kekambuhan endometriosis dengan model regresi. Faktor asupan makanan sebagai variabel independen dan waktu kambuh adalah variabel dependen.

\section{METODE PENELITIAN}

\subsection{Sumber Dan Teknik Pengumpulan Data}

Penelitian ini merupakan penelitian observasi. Data yang digunakan dalam penelitan ini merupakan data primer. Sumber data penelitian adalah responden wanita dengan endometriosis yang sudah pernah menjalani terapi pembedahan dengan laparoskopi atau laparotomi. Data dikumpulkan dengan metode survei menggunakan kuesioner secara online dengan gogle form pada komunitas endometriosis di grup WhatsApp maupun offline melalui tatap muka langsung dengan responden. Data dikumpulkan pada bulan JanuariFebruari 2019. Teknik pengambilan sampel yang digunakan adalah pengambilan sampel non peluang (purposive sampling dan snowball sampling).

Kuesioner dibagi menjadi beberapa bagian yaitu 1) Identitas responden (berisi nama, tempat tanggal lahir, status pernikahan, alamat dan lain-lain yang terkait dengan identitas responden), 2) Riwayat endometriosis pertama kali, berisi pertanyaan tentang waktu pertama kali didiagnosis endometriosis oleh dokter, usia pertama kali didiagnosis, jenis, ukuran, letak dan stadium endometriosisnya serta status pernikahan saat pertama kali didiagosis. 3) Riwayat Pengobatan yaitu jenis pengobatan yang diterima, jenis operasi, waktu operasi dan status kekambuhan setelah operasi dan waktu kambuh. 4) Frekuensi konsumsi buah, sayur, kedelai, susu, kafein, daging merah, bawang putih, jahe, seafood, keju, teh hijau, beras merah, gandum, kentang, tauge, sawi, minuman bersoda, dengan frekuensi 1. Hampir tidak pernah. 2. 1-3 hari / bulan, 3. 1-2 hari / minggu. 4. 3-4 hari / minggu 5. 5-7 hari / minggu, sedangkan konsumsi alkohol merupakan variabel biner ya atau tidak.

\subsection{Metode Analisis}

Variabel yang digunakan dalam pemodelan terdiri dari variabel independen yaitu faktor asupan makanan dan variabel dependen yaitu waktu kambuh endometriosis setelah operasi pertama (dalam bulan). Variabel independen adalah asupan / konsumsi kafein, soda, kedelai, daging merah, susu, alkohol, seafood, mentega (lemak trans), gandum (gluten), tauge, sawi, buah, jahe, bawang putih, teh hijau. Waktu kambuh dihitung sejak operasi sebagai waktu awal (time origin) sampai terjadinya kekambuhan lesi endometriosis berdasarkan diagnosis dokter (end point), dihitung dalam bulan.

Metode analisis penelitian dilakukan sebagai berikut;

1. Mendeskripsikan data karakteristik responden dan faktor-faktor asupan makanan.

2. Pengujian pengaruh faktor dengan model regresi Cox atau model hazard proporsional Cox. Model regresi Cox atau model hazard proporsional Cox dapat dituliskan seperti berikut [19] 


$$
h(t, \mathbf{X})=h_{0}(t) e^{\sum_{i=1}^{p} \beta_{i} X_{i}}
$$

dengan $h(t, \mathbf{X})$ adalah hazard kematian individu pada waktu $\mathrm{t}$ dengan vector variabel bebas / faktor risiko $\mathbf{X}=\left(\mathrm{X}_{1}, \mathrm{X}_{2}, \ldots, \mathrm{X}_{p}\right), h_{0}(t)$ adalah fungsi hazard dasar pada saat $\mathbf{X}=\mathbf{0}$ dan $\beta_{\boldsymbol{i}}$ dalah parameter regresi ke $-\mathrm{i}(\mathrm{i}=1,2, \ldots, \mathrm{p})$ dari variabel bebas ke-i, $\mathrm{X}_{\boldsymbol{i}}$.

Pendugaan parameter $\beta_{\boldsymbol{i}}$ pada pada persamaan (1) dilakukan dengan metode kemungkinan partial likelihood (maximum partial likelihood estimation/ MPLE) dengan metode iterasi Newton Rhapson [19]. Untuk menguji faktor risiko yang berpengaruh secara keseluruhan dilakukan dengan uji rasio partial likelihood, dengan hipotesis $\mathrm{H}_{0}: \forall \beta_{i}=0$ dan $\mathrm{H}_{1}: \exists \beta_{i} \neq 0, i=1,2, \ldots, p$. Statistik uji rasio partial likelihood adalah sebagai berikut:

$$
G=-2\left[\operatorname{Ln} L_{R}-\ln L_{f}\right]
$$

dengan $L_{R}$ adalah partial likelihood model awal yaitu model model regresi sebelum semua variabel X dimasukkan dan $L_{f}$ adalah partial likelihood model akhir yaitu model regersi setelah semua variabel $\mathrm{X}$ dimasukkan dalam model. Kriteria keputusan yaitu $\mathrm{H}_{0}$ ditolak jika $G \geq \chi_{(\alpha ; d b=p)}^{2}$, dengan $p$-value $\alpha$ dan $\mathrm{db}$ (derajat bebas) $\mathrm{p}$, berarti minimal ada satu $\beta_{i} \neq 0$ atau minimal ada satu faktor yang signifikan. Sedangkan untuk menguji pengaruh faktor secara parsial digunakan uji Wald, dengan hipotesis $\mathrm{H}_{\mathbf{0}}: \beta_{i}=$ 0 dan $\mathrm{H}_{1}: \beta_{i} \neq 0$, dengan $i=1,2, \ldots, p$. Statistik uji Wald adalah

$$
Z^{2}=\left(\frac{\widehat{\beta}_{i}}{S E \widehat{\beta}_{i}}\right)^{2}
$$

Kriteria keputusan yaitu tolak $\mathrm{H}_{0}$ jika $Z^{2} \geq \chi_{(\alpha ; d b=p)}^{2}$, dengan $p$-value $\alpha$ dan db (derajat bebas) $\mathrm{p}$, berarti $\beta_{i} \neq 0$ atau faktor $X_{i}$ signifikan [18]. Selanjutnya dilakukan uji pengaruh dengan metode backward untuk memilih model dengan subset variabel bebas yang signifikan. Prosedur metode backward dimulai dengan model penuh yaitu model dengan semua variabel bebas ada dalam model. Selanjutnya variabel dengan nilai $p$-value paling besar dikeluarkan satu persatu pada setiap langkah. Proses dihentikan sampai diperoleh model dengan semua variabel signifikan pada $p$-value tertentu. Pada setiap Langkah dilakukan pengujian signifikansi variabel secara simultan dengan uji uji rasio partial likelihood dan secara parsial dengan uji Wald [20].

3. Pengujian asumsi proporsional hazard

Model Cox mengasumsikan bahwa hazard antar individu proporsial atau disebut juga asumsi hazard proporsional. Pengujian asumsi proporsional hazard dapat dilakukan dengan uji goodness of fit (GOF). Uji goodness of fit dilakukan dengan menghitung korelasi antara nilai residual scoenfeld setiap variabel independen dengan waktu survival yang telah diurutkan untuk semua waktu survival yang tidak tersensor. Korelasi (r) bivariat setiap variabel tehadap waktu survival yang terurut merupakan statistik uji dari pengujian asumsi proporsional hazard dan hasil uji signifikansi $r$ merupakan hasil uji asumsi tersebut. Jika $\mathrm{r}$ tidak signifikan pada taraf signifikansi tertentu maka asumsi proporsional hazard terpenuhi [19].

4. Menginterpretasikan hasil analisis

Model Regresi Cox dapat diinterpretasikan dari nilai hazard rasio (HR), dimana HR menunjukkan risiko peningkatan atau penurunan risiko individu dengan karakteristik tertentu. Hazard rasio antara dua individu dengan karakteristik tertentu dapat dituliskan sebagai berikut:

$$
H R=\frac{h\left(t, \mathrm{X}_{1}\right)}{h\left(t, \mathrm{X}_{0}\right)}=\frac{\exp \left(\beta X_{1}\right)}{\exp \left(\beta X_{0}\right)}=\exp \left(X_{1}-X_{0}\right) \beta, \forall t>0
$$

HR menyatakan besarnya rasio relatif seorang individu dengan faktor risiko tertentu bernilai $X_{1}$ terhadap individu dengan faktor risiko bernilai $X_{0}$. Nilai dugaan parameter $\beta_{i}$ dapat digunakan untuk interpretasi nilai hazard sebagai berikut

1. Nilai $\beta_{i}>0$ menunjukkan bahwa peningkatan nilai $X_{i}$ akan memperbesar nilai hazard atau risiko individu mengalami kejadian.

2. Nilai $\beta_{i}<0$ menunjukkan bahwa peningkatan nilai $X_{i}$ akan memperkecil nilai hazard atau risiko individu mengalami kejadian [18]. 


\section{HASIL DAN PEMBAHASAN}

\subsection{Deskripsi Data}

Dari survei yang telah dilakukan, diperoleh data 53 orang responden yang pernah menjalani operasi (laparoskopi, laparotomi dan histerektomi). Pada penelitian ini hanya digunakan data responden yang menjalani operasi laparoskopi dan laparotomi, yaitu berjumlah 49 orang. Ringkasan data 49 orang responden dapat dilihat pada Tabel 1.

Tabel 1. Ringkasan data karakteristik 49 responden

\begin{tabular}{lrrrr}
\hline Karakteristik responden & \multicolumn{1}{c}{ Minimum } & \multicolumn{1}{c}{ Maksimum } & Rata-rata & Std. Deviation \\
\hline Umur (tahun) & 21 & 45 & 32,53 & 6.662 \\
\hline Berat Badan (kg) & 40 & 95 & 58,47 & 11.509 \\
\hline Tinggi Badan (cm) & 145 & 170 & 157,53 & 4.792 \\
\hline $\begin{array}{l}\text { Ukuran Endometriosis saat } \\
\text { diagnosis (cm) }\end{array}$ & 0,15 & 20 & 5,65 & 4.237 \\
\hline Umur Saat Diagnosis (tahun) & 14 & 44 & 27.82 & 6.451 \\
\hline Waktu Survival (bulan) & 1 & 72 & 18.37 & 19.450 \\
\hline
\end{tabular}

Pada Tabel 1, dapat dilihat ringkasan numerik umur, berat badan dan tinggi badan responden saat penelitian, ukuran endometriosis dan umur saat didiagnosis endometriosis pertama kali, serta waktu survival responden. Umur minimum dan maksimum saat penelitian adalah 21 dan 45 tahun, dengan umur rata-rata adalah 32 tahun 5 bulan. Umur minimum saat responden didiagnosis pertama kalinya adalah 14 tahun dan maksimun 44 tahun, dengan umur rata-rata adalah 27 tahun 8 bulan. Ukuran endometriosis saat operasi menyatakan ukuran diameter lesi endometriosis yang paling besar pada saat operasi, diukur dalam $\mathrm{cm}$. Dapat dilihat ukuran endometriosis saat operasi ada yang mencapai $20 \mathrm{~cm}$. Deskripsi karakteristik responden lainnya dapat dilihat pada Tabel 2.

Tabel 2. Frekuensi dan persentase responden berdasarkan data kategorik

\begin{tabular}{llll}
\hline Variabel & Kategori & Frekuensi & Persentase \\
\hline Jenis Operasi & Laparatomi & 18 & 36.7 \\
\hline & Laparaskopi & 31 & 63.3 \\
\hline Jumlah operasi & 1 kali & 18 & 36.7 \\
\hline & 2 kali & 31 & 63.3 \\
\hline Jumlah Lesi & Satu & 35 & 71.4 \\
\hline & Dua & 10 & 20.4 \\
\hline Status Sensor & 3 atau lebih & 4 & 8.2 \\
\hline & tersensor & 26 & 53.1 \\
\hline & Tidak tersensor & 23 & 46.9 \\
\hline
\end{tabular}

Pada Tabel 2, responden lebih banyak yang menjalani operasi dengan laparaskopi yaitu 31 orang $(63,3 \%) .31(63,3 \%)$ orang responden sudah pernah mengalami operasi sebanyak 2 kali dan sisanya 1 kali. Responden yang tersensor atau tidak mengalami kejadian kambuh ada sebanyak 26 orang $(53,1 \%)$ dan sisanya mengalami kejadian kambuh. Jumlah lesi terbanyak adalah 1, yaitu sebanyak 35 orang $(71,4 \%)$.

Frekuensi dan persentase setiap faktor asupan makanan setelah dikode ulang dapat dilihat pada Tabel 3. Semua faktor asupan makanan pada Tabel 3 dianalisis pengaruhnya terhadap waktu kambuh endometriosis, kecuali faktor alkohol, karena jawaban responden yang seragam, hanya 1 responden yang menjawab mengkonsumsi alkohol, sedangkan sisanya 48 orang $(97,9 \%)$ tidak mengkonsumsi alkohol.

Tabel 3. Frekuensi dan persentase responden berdasarkan faktor asupan makanan

\begin{tabular}{lrrr} 
Faktor Makanan & Kategori & Frekuensi & Persentase (\%) \\
\hline Buah & $<1 \mathrm{kali} /$ minggu & 4 & 8.2 \\
\hline & 1-4 kali / minggu & 25 & 51.5 \\
\hline Susu & 5-7 kali / minggu & 20 & 40.8 \\
\hline & $<1 \mathrm{kali} /$ minggu & 15 & 30.6 \\
\hline & 1-2 kali / minggu & 13 & 26.5 \\
\hline
\end{tabular}




\begin{tabular}{|c|c|c|c|}
\hline Faktor Makanan & Kategori & Frekuensi & Persentase (\%) \\
\hline & 5-7 kali / minggu & 13 & 26.5 \\
\hline \multirow[t]{3}{*}{ Kedelai } & $<1 \mathrm{kali} /$ minggu & 12 & 24.5 \\
\hline & 1-2 kali / minggu & 16 & 32.7 \\
\hline & 3-7 kali / minggu & 21 & 42.9 \\
\hline \multirow{3}{*}{ Seafood } & $<1 \mathrm{kali} /$ minggu & 27 & 55.1 \\
\hline & 1-2 kali / minggu & 14 & 28.6 \\
\hline & 3-7 kali / minggu & 8 & 16.3 \\
\hline \multirow[t]{2}{*}{ Kafein } & $<1 \mathrm{kali} /$ minggu & 31 & 63.3 \\
\hline & 1-7 kali / minggu & 18 & 36.7 \\
\hline \multirow[t]{3}{*}{ Bawang Putih } & $<3 \mathrm{kali} /$ minggu & 7 & 4.3 \\
\hline & 3-4 kali / minggu & 11 & 22.4 \\
\hline & 5-7 kali / minggu & 31 & 63.3 \\
\hline \multirow[t]{3}{*}{ Mentega } & $<1$ kali / bulan & 21 & 42.9 \\
\hline & 1-3 kali / bulan & 12 & 24.5 \\
\hline & 1-4 kali / minggu & 16 & 32.7 \\
\hline \multirow[t]{3}{*}{ Jahe } & $<1 \mathrm{kali} /$ minggu & 27 & 55.1 \\
\hline & 1-2 kali / minggu & 13 & 26.5 \\
\hline & 3-7 kali / minggu & 9 & 18.4 \\
\hline \multirow[t]{2}{*}{ Gandum } & $<1 \mathrm{kali} /$ minggu & 21 & 42.9 \\
\hline & 1-4 kali / minggu & 28 & 57.1 \\
\hline \multirow[t]{2}{*}{ Daging Merah } & $<1 \mathrm{kali} /$ minggu & 29 & 59.2 \\
\hline & 1-7 kali / minggu & 20 & 40.8 \\
\hline \multirow[t]{3}{*}{ Tauge } & $<1 \mathrm{kali} / \mathrm{minggu}$ & 24 & 49.0 \\
\hline & 1-2 kali / minggu & 11 & 22.4 \\
\hline & 3-7 kali / minggu & 14 & 28.6 \\
\hline \multirow[t]{3}{*}{ Kentang } & $<1$ kali / bulan & 10 & 20.8 \\
\hline & 1-3 kali / bulan & 23 & 47.9 \\
\hline & 1-7 kali / minggu & 15 & 31.2 \\
\hline \multirow[t]{2}{*}{ Beras Merah } & $<1$ kali / bulan & 36 & 73.5 \\
\hline & 1-3 kali / bulan & 13 & 26.5 \\
\hline \multirow[t]{2}{*}{ Sawi } & $<1 \mathrm{kali} /$ minggu & 34 & 69.4 \\
\hline & 1-7 kali / minggu & 15 & 30.6 \\
\hline \multirow[t]{2}{*}{ Soda } & $<1$ kali / bulan & 42 & 85.7 \\
\hline & $>1$ kali / bulan & 7 & 14.3 \\
\hline \multirow[t]{3}{*}{ Keju } & $<1$ kali / bulan & 18 & 36.7 \\
\hline & 1-3 kali / bulan & 15 & 30.6 \\
\hline & 1-7 kali / minggu & 16 & 32.7 \\
\hline \multirow[t]{2}{*}{ Teh Hijau } & $<1$ kali / bulan & 28 & 57.1 \\
\hline & $>1 \mathrm{kali} /$ bulan & 21 & 42.9 \\
\hline \multirow[t]{2}{*}{ Alkohol } & Tidak & 48 & 97.9 \\
\hline & Ya & 1 & 2.1 \\
\hline
\end{tabular}

\subsection{Analisis Pengaruh dengan Model Hazard Proporsional Cox}

Pengaruh faktor asupan makanan terhadap risiko kekambuhan endometriosis dilakukan dengan model hazard proporsional Cox. Faktor asupan makanan yang dianalisis adalah semua yang ada pada Tabel 3, kecuali faktor alkohol. Semua faktor merupakan variabel kategori. Kategori pertama dijadikan sebagai baseline kategori dalam pemodelan.

Proses pengujian pengaruh faktor asupan makanan terhadap waktu kekambuhan endometriosis dimulai dengan pengujian pengaruh faktor secara serempak (simultan). Hasil pengujian pengaruh faktor asupan makanan secara serempak dapat dilihat pada tabel 4 berikut ini.

\section{Tabel 4. Hasil uji pengaruh faktor secara serempak}

\begin{tabular}{ccccc}
\hline Uji & Chi-square & df & $\boldsymbol{p}$-value & Keputusan \\
\hline Likelihood Ratio & 55.608 & 28 & .001 & Tolak $\mathrm{H}_{0}$ \\
\hline
\end{tabular}

Pada Tabel 4 dapat dilihat nilai uji likelihood rasio secara simultan adalah 55.608 dengan derajat bebas 28 , nilai $p$-value 0,001 . Hasil uji secara keseluruhan adalah signifikan jika diambil taraf signifikansi $5 \%$ atau 
0,05. Berarti minimal terdapat satu faktor asupan makanan yang berpengaruh terhadap risiko kekambuhan endometriosis setelah operasi pertama kali.

Setelah dilakukan pengujian secara simultan, selanjutnya dilakukan pengujian pengaruh masingmasing faktor asupan makanan secara parsial, dengan menggunakan uji Wald. Hasil pengujian pengaruh faktor secara parsial dapat dilihat pada Tabel 5. Pada Tabel 5., diberikan nilai dugaan koefisien masingmasing faktor, nilai uji wald, $p$-value dan hazard rasio masing-masing kategori faktor. Pada Tabel 5, dapat dilihat faktor asupan makanan yang signifikan berpengaruh terhadap kekambuhan pasien dengan endometrisis setelah operasi pertama pada taraf 5\% $(0,05)$ yaitu konsumsi seafood (1) ( $p$-value $=0,002)$, seafood (2) ( $p$-value $=0,003)$, susu (1) ( $p$-value 0,042), susu (2) ( $p$-value 0,011), bawang putih (1) ( $p$-value $0,039)$, Buah (1) ( $p$-value $=0,007)$, Tauge $(2)(p$-value $=0,026)$, kedelai $(1)(p$-value 0,012$)$ dan kedelai $(2)$ ( $p$-value 0,016$)$. Faktor asupan makanan yang signifikan pada taraf $10 \%(0,1)$ adalah kentang (1) ( $p$-value $0,096)$, sawi ( $p$-value 0,061$)$ dan buah (2) ( $p$-value 0,088$)$. Sedangkan faktor lain tidak signifikan pada taraf $10 \%$.

Tabel 5. Hasil pengujian pengaruh faktor secara parsial

\begin{tabular}{|c|c|c|c|c|c|c|}
\hline Faktor & Koefisien & $\begin{array}{c}\text { Standar } \\
\text { Error }\end{array}$ & Wald & $\begin{array}{c}\text { Derajat } \\
\text { Bebas }\end{array}$ & P-value & $\begin{array}{c}\text { Hazard } \\
\text { Rasio }\end{array}$ \\
\hline Seafood & & & 13.773 & 2 & .001 & \\
\hline Seafood (1) & 5.705 & 1.801 & 10.034 & 1 & .002 & 300.449 \\
\hline Seafood (2) & -12.981 & 4.408 & 8.671 & 1 & .003 & .000 \\
\hline susu & & & 11.980 & 3 & .007 & \\
\hline Susu (1) & -3.261 & 1.603 & 4.137 & 1 & .042 & .038 \\
\hline Susu (2) & 6.503 & 2.557 & 6.471 & 1 & .011 & 667.369 \\
\hline Susu (3) & -.272 & 1.862 & .021 & 1 & .884 & .762 \\
\hline Bawang Putih & & & 4.668 & 2 & .097 & \\
\hline Bawang Putih (1) & 5.269 & 2.554 & 4.254 & 1 & .039 & 194.161 \\
\hline Bawang Putih (2) & 1.974 & 2.177 & .822 & 1 & .365 & 7.198 \\
\hline Gandum & -2.591 & 1.786 & 2.105 & 1 & .147 & .075 \\
\hline The Hijau & -.064 & 1.312 & .002 & 1 & .961 & .938 \\
\hline Kentang & & & 3.865 & 2 & .145 & \\
\hline Kentang (1) & 4.182 & 2.509 & 2.778 & 1 & .096 & 65.473 \\
\hline Kentang (2) & 3.106 & 4.081 & .579 & 1 & .447 & 22.331 \\
\hline Sawi & -2.632 & 1.402 & 3.522 & 1 & .061 & .072 \\
\hline Beras Merah & 1.884 & 1.716 & 1.206 & 1 & .272 & 6.578 \\
\hline Keju & & & 2.373 & 2 & .305 & \\
\hline Keju (1) & 2.763 & 1.851 & 2.228 & 1 & .136 & 15.847 \\
\hline Keju (2) & 1.662 & 2.251 & .545 & 1 & .460 & 5.269 \\
\hline Soda & 2.920 & 3.409 & .733 & 1 & .392 & 18.534 \\
\hline Jahe & & & .242 & 2 & .886 & \\
\hline Jahe (1) & .360 & 1.631 & .049 & 1 & .825 & 1.434 \\
\hline Jahe (2) & -.612 & 1.380 & .197 & 1 & .657 & .542 \\
\hline Buah & & & 7.349 & 2 & .025 & \\
\hline Buah(1) & -7.548 & 2.784 & 7.350 & 1 & .007 & .001 \\
\hline Buah(2) & -4.677 & 2.712 & 2.974 & 1 & .085 & .009 \\
\hline Tauge & & & 5.454 & 2 & .065 & \\
\hline Tauge(1) & -.205 & 1.660 & .015 & 1 & .901 & .814 \\
\hline Tauge(2) & -5.115 & 2.296 & 4.962 & 1 & .026 & .006 \\
\hline Kafein & -1.154 & 1.383 & .696 & 1 & .404 & .315 \\
\hline Daging Merah & 2.931 & 2.024 & 2.097 & 1 & .148 & 18.748 \\
\hline
\end{tabular}


Tabel 5. Hasil pengujian pengaruh faktor secara parsial (lanjutan)

\begin{tabular}{lcccccc}
\hline \multicolumn{1}{c}{ Faktor } & Koefisien & $\begin{array}{c}\text { Standar } \\
\text { Error }\end{array}$ & Wald & $\begin{array}{c}\text { Derajat } \\
\text { Bebas }\end{array}$ & $\boldsymbol{P}$-value & $\begin{array}{c}\text { Hazard } \\
\text { Rasio }\end{array}$ \\
\hline Mentega & & & 1.249 & 2 & .535 & \\
\hline Mentega(1) & -3.175 & 2.841 & 1.249 & 1 & .264 & .042 \\
\hline Mentega(2) & -2.263 & 2.381 & .903 & 1 & .342 & .104 \\
\hline Kedelai & & & 6.949 & 2 & .031 & \\
\hline Kedelai(1) & 7.083 & 2.813 & 6.343 & 1 & .012 & $1.192 \mathrm{E} 3$ \\
\hline Kedelai(2) & 8.667 & 3.602 & 5.789 & 1 & .016 & $5.808 \mathrm{E} 3$ \\
\hline
\end{tabular}

Selanjutnya dilakukan uji pengaruh dengan metode backward. Hasil uji secara simultan, signifikan pada $p$-value 0,03 pada Langkah ke 12. Hasil uji dengan metode backward secara parsial dengan uji Wald dapat dilihat pada Tabel 6.

Tabel 6. Hasil pengujian pengaruh faktor dengan metode backward stepwise

\begin{tabular}{lrrrrr}
\hline Faktor & Koefisien & Standar Error & Wald & \multicolumn{2}{r}{$\boldsymbol{P}$-value Hazard Rasio } \\
\hline Seafood & & & 20.041 & .000 & \\
\hline Seafood (1) & 3.882 & .961 & 16.339 & .000 & 48.562 \\
\hline Seafood (2) & -3.783 & 1.655 & 5.226 & .022 & .023 \\
\hline susu & & & 16.856 & .001 & \\
\hline susu (1) & -1.194 & .809 & 2.178 & .140 & .303 \\
\hline susu (2) & 3.212 & 1.130 & 8.084 & .004 & 24.833 \\
\hline susu (3) & .187 & .781 & .057 & .811 & 1.205 \\
\hline Sawi & -1.977 & .724 & 7.460 & .006 & .139 \\
\hline Buah & & & 8.272 & .016 & \\
\hline Buah (1) & -3.344 & 1.314 & 6.472 & .011 & .035 \\
\hline Buah (2) & -2.171 & 1.274 & 2.906 & .088 & .114 \\
\hline Tauge & & & 7.193 & .027 & \\
\hline Tauge (1) & -.699 & .740 & .894 & .344 & .497 \\
\hline Tauge (2) & -2.293 & .855 & 7.182 & .007 & .101 \\
\hline Kedelai & & & 12.330 & .002 & \\
\hline Kedelai (1) & 3.412 & 1.077 & 10.035 & .002 & 30.320 \\
\hline Kedelai (2) & 3.782 & 1.112 & 11.575 & .001 & 43.895 \\
\hline
\end{tabular}

Hasil pengujian pengaruh faktor risiko dengan menggunakan metode backward pada Tabel 7, memperlihatkan bahwa ada 6 faktor yang signifikan terhadap risiko kekambuhan endometriosis pada $p$-value 0,05 yaitu seafood (1), seafood (2), susu (2), sawi, buah (1), tauge (2), kedelai (2) dan kedelai (1). Faktor buah (2) signifikan pada nilai p 0,1 .

Faktor konsumsi seafood (1) yaitu konsumsi seafood 1-2 kali perminggu dibandingkan konsumsi seafood kurang dari 1 kali perminggu signifikan pada $p$-value 0,05 dengan hazard rasio 48,562 berarti risiko kambuh untuk konsumsi seafood 1-2 kali perminggu 48 kali dibandingkan yang konsumsi seafood kurang dari 1 kali perminggu. Sedangkan risiko kekambuhan konsumsi seafood (2) yaitu konsumsi seafood 3-4 kali perminggu malah mengurangi risiko kekambuhan endometriosis dibandingkan yang konsumsi seafood kurang dari 1 kali perminggu, dengan faktor lainnya dianggap konstan.

Hazard rasio faktor susu (2) yaitu konsumsi susu 3-4 kali perminggu adalah 24,827, yang berarti risiko kambuhnya 24 kali dibandingkan yang konsumsi susu kurang dari 1 kali perminggu, dengan faktor lainnya konstan. Hal ini kontras dengan hasil penelitian Trabert et al [6] dan Youseflu et al [14], yang menyatakan peningkatan konsumsi susu terkait dengan penurunan risiko endometriosis. Akan tetapi penelitian Trabert et al [6] dan youseflu et al [14] bukan tentang pengaruh asupan makan terhadap kekambuhan endometriosis melainkan peningkatan kejadian endometriosis dibandingkan pasien yang bukan endometriosis.

Faktor konsumsi buah dapat mengurangi risiko kekambuhan endometriosis, dimana untuk faktor buah (1) yaitu konsumsi buah 1-4 kali perminggu mempunyai hazard rasio 0,035 terhadap konsumsi buah kurang 
dari 1 kali perminggu. Faktor buah (2) yaitu konsumsi buah 5-7 kali perminggu juga memberikan risiko kambuh lebih kecil yaitu 0.11 dibandingkan yang konsumsi buah kurang dari 1 kali perminggu pada taraf signifikansi $10 \%(0,1)$. Hasil ini sejalan dengan penelitian [11][13][14], bahwa konsumsi buah yang tinggi dikaitkan dengan risiko kejadian endometriosis yang rendah dibandingkan pasien bukan endometriosis.

Konsumsi sayur sawi memberikan pengaruh positif terhadap penurunan risiko kambuh endometriosis, yaitu konsumsi sayur sawi 1-7 kali perminggu resikonya kekambuhan lebih kecil yaitu 0,139 dibandigkan yang konsumsi sawi $<1$ kali perminggu, dengan faktor lainnya konstan. Demikian juga dengan konsumsi sayur tauge, berpengaruh positif terhadap penurunan risiko kambuh endometriosis. Faktor konsumsi tauge (2) yaitu konsumsi tauge 3-7 kali perminggu, memberikan pengaruh positif terhadap penurunan risiko kekambuhan endometriosis, yaitu konsumsi tauge 3-7 kali perminggu mempunyai rasio hazard 0,101 terhadap konsumsi tauge < 1 kali perminggu. Sedangkan konsumsi tauge 1-2 kali perminggu tidak signifikan pada taraf 5\% terhadap konsumsi tauge kurang dari 1 kali perminggu. Hal ini sejalan dengan penelitian [11][10][14] yaitu konsumsi tinggi sayur-sayuran dikaitkan dengan risiko endometriosis yang lebih rendah diantara pasien wanita dengan endometriosis dibandingkan yang bukan endometriosis.

Konsumsi kedelai, memberikan pengaruh negatif terhadap risiko kekambuhan endometriosis, dimana faktor kedelai (1) yaitu konsumsi kedelai 1-3 kali perminggu mempunyai nilai hazard rasio 30,32 terhadap konsumsi kedelai kurang dari 1 kali per minggu yang berarti risiko kambuh pasien yang konsumsi kedelai 13 kali perminggu mempunyai kemungkinan kambuh 30,32 kali dibandingkan yang konsumsi kedelai <1 kali perminggu. Faktor kedelai (2) yaitu konsumsi kedelai 4-7 kali perminggu mempunyai risiko kambuh 43,895 kali dibandingkan yang konsumsi kedelai lebih kecil dari 1 kali perminggu dengan faktor lainnya dianggap konstan. Semakin bertambah frekuensi konsumsi kedelai maka makin meningkatkan risiko kambuh. Hasil ini sejalan dengan penlitian [17] yang mengatakan bahwa konsumsi kedelai dapat meningkatkan endometriosis.

\subsection{Pengujian Asumsi Proporsional Hazard}

Pengujian asumsi proporsional hazard dilakukan dengan uji goodness of fit (GOF) untuk faktor pada pemodelan dengan hazard proporsional Cox. Uji goodness of fit dilakukan dengan menghitung korelasi antara nilai residual scoenfeld setiap variabel independen dengan waktu survival yang telah diurutkan untuk semua waktu kambuh yang tidak tersensor. Korelasi (r) bivariat setiap variabel tehadap waktu survival yang terurut merupakan statistik uji dari pengujian asumsi proporsional hazard dan hasil uji signifikansi $\mathrm{r}$ merupakan hasil uji asumsi tersebut [19].

Hasil pengujian GOF setiap faktor yang telah dimodelkan dengan model hazard proporsional (Tabel 5) disajikan pada Tabel 7. Pada Tabel 7, dapat dilihat nilai $p$-value dari semua faktor dimana semua faktor asupan makanan menunjukkan nilai $p$-value yang lebih besar dari 0,05 , berarti asumsi proporsional hazard tidak dilanggar atau terpenuhi untuk semua faktor.

Tabel 7. Uji asumsi hazard proporsional Cox

\begin{tabular}{lcclcc}
\hline Faktor & $\mathbf{r}$ & $\boldsymbol{p}$-value & Faktor & $\mathbf{r}$ & $\boldsymbol{p}$-value \\
\hline Seafood & & & Soda & 0,116 & 0,598 \\
\hline Seafood (1) & 0,134 & 0,541 & Jahe & & \\
\hline Seafood (2) & 0,205 & 0,348 & Jahe (1) & 0,044 & 0,841 \\
\hline susu & & & Jahe (2) & $-0,057$ & 0,797 \\
\hline susu (1) & -0.03 & 0,893 & Buah & & \\
\hline susu (2) & 0,329 & 0,125 & Buah (1) & $-0,145$ & 0,508 \\
\hline susu (3) & $-0,083$ & 0,705 & Buah (2) & 0,043 & 0,844 \\
\hline
\end{tabular}


Tabel 7. Uji asumsi hazard proporsional Cox (lanjutan)

\begin{tabular}{lcclcc}
\hline Faktor & $\mathbf{r}$ & $\boldsymbol{p}$-value & Faktor & $\mathbf{r}$ & $\boldsymbol{p}$-value \\
\hline Bawang Putih & \multicolumn{5}{c}{ Tauge } \\
\hline Bawang Putih (1) & 0,254 & 0,483 & Tauge (1) & $-0,076$ & 0,732 \\
\hline Bawang Putih (2) & 0,191 & 0,382 & Tauge (2) & 0,098 & 0,657 \\
\hline Gandum & 0,324 & 0,131 & Kafein & 0,266 & 0,220 \\
\hline TehHijau & $-0,035$ & 0,875 & Daging Merah & 0,200 & 0,359 \\
\hline Kentang & & Mentega & & \\
\hline Kentang (1) & $-0,112$ & 0,609 & Mentega (1) & 0,025 & 0,909 \\
\hline Kentang (2) & 0,142 & 0,518 & Mentega (2) & 0,262 & 0,227 \\
\hline SawiNew2 & $-0,031$ & 0,890 & Kedelai & & \\
\hline Beras Merah & 0,045 & 0,838 & Kedelai (1) & $-0,031$ & 0,887 \\
\hline Keju & & & Kedelai (2) & $-0,163$ & 0,457 \\
\hline Keju (1) & $-0,002$ & 0,992 & & & \\
\hline Keju (2) & 0,021 & 0,926 & & &
\end{tabular}

\section{KESIMPULAN}

Kesimpulan yang diperoleh dari hasil penelitian adalah faktor makanan dapat menurunkan kemungkinan risiko kekambuhan dan meningkatkan kemungkinan risiko kekambuhan pasien endometriosis setelah operasi pertama. Faktor konsumsi makanan yang menurunkan risiko kekambuhan endometriosis adalah konsumsi buah, sayur sawi dan sayur tauge. Faktor makanan yang meningkatkan risiko kambuh adalah susu dan kedelai. Sedangkan konsumsi seafood bisa meningkatkan dan menurunkan risiko kekambuhan endometriosis. Faktor konsumsi makanan lainnya yaitu jahe, mentega (lemak trans), daging merah, kafein, bawang putih, gandum (gluten), teh hijau, kentang, beras merah, keju dan minuman bersoda tidak signifikan pada taraf signifikansi 5\%. Konsumsi buah 1-4 kali dan 5-7 kali per minggu mempunyai hazard rasio 0,035 dan 0,114 terhadap konsumsi buah kurang dari 1 kali per minggu. Konsumsi sawi 1-7 kali perminggu resikonya kekambuhan lebih kecil yaitu 0,139 dibandigkan yang konsumsi sawi < 1 kali per minggu. Konsumsi tauge 3-7 kali per minggu mempunyai rasio hazard 0,101 terhadap konsumsi tauge $<1$ kali perminggu. Konsumsi kedelai 1-3 kali per minggu mempunyai kemungkinan kambuh 30,32 kali dibandingkan yang konsumsi kedelai <1 kali per minggu dan konsumsi kedelai 4-7 kali per minggu mempunyai risiko kambuh 43,89 kali dibandingkan yang konsumsi kedelai $<1$ kali per minggu dengan faktor lainnya dianggap konstan. Konsumsi susu 3-4 kali perminggu mempunyai risiko kambuh 24 kali dibandingkan yang konsumsi susu $<1$ kali per minggu. Konsumsi seafood 1-2 kali mempunyai risiko kambuh 48 kali dibandingkan yang konsumsi seafood $<1$ kali per minggu, kontras dengan konsumsi seafood 3-4 kali perminggu mempnyai risiko kambuh lebih keci dibandingkan konsumsi seafood $<1$ kali per minggu.

\section{UCAPAN TERIMA KASIH}

Terima kasih kami sampaikan kepada responden yang sudah berpartisipasi dalam penelitian, kepada mahasiswa yang sudah membantu dalam survei dan kepada Lembaga Penelitian dan Pengabdian kepada Masyarakat (LPPM) Universitas Sriwijaya.

\section{DAFTAR PUSTAKA}

[1] A. Korespondensi, G. Meisadona, A. D. Soebroto, and R. Estiasari, "TINJAUAN PUSTAKA Diagnosis dan Tatalaksana Meningitis Bakterialis," vol. 42, no. 1, pp. 15-19, 2015.

[2] T. Willy, "Endometriosis; Diagnosis dan Pengobatan Endometriosis," 2018. https://www.alodokter.com/endometriosis.

[3] K. Koga, M. Takamura, T. Fujii, and Y. Osuga, "Prevention of the recurrence of symptom and lesions after conservative surgery for endometriosis," Fertil. Steril., vol. 104, no. 4, pp. 793-801, 2015, doi: 10.1016/j.fertnstert.2015.08.026. 
[4] M. L. Sperschneider et al., "Does endometriosis affect professional life? A matched case-control study in Switzerland, Germany and Austria," BMJ Open, vol. 9, no. 1, pp. 1-11, 2019, doi: 10.1136/bmjopen-2017-019570.

[5] F. Facchin et al., "Impact of endometriosis on quality of life and mental health: Pelvic pain makes the difference," $J$. Psychosom. Obstet. Gynecol., vol. 36, no. 4, pp. 135-141, 2015, doi: 10.3109/0167482X.2015.1074173.

[6] B. Trabert, U. Peters, A. J. De Roos, D. Scholes, and V. L. Holt, "Diet and risk of endometriosis in a population-based case-control study," Br. J. Nutr., vol. 105, no. 3, pp. 459-467, 2011, doi: 10.1017/S0007114510003661.

[7] J. Jurkiewicz-Przondziono, M. Lemm, A. Kwiatkowska-Pamula, E. Ziólłko, and M. K. Wójtowicz, "Influence of diet on the risk of developing endometriosis," Ginekol. Pol., vol. 88, no. 2, pp. 96-102, 2017, doi: 10.5603/GP.a2017.0017.

[8] R. C. Swari, "Panduan Pola Makan untuk Wanita Penderita EndometriosisNo Title,” 2019. https://hellosehat.com/nutrisi/diet/makanan-untuk-endometriosis-adalah/\#gref.

[9] O. T. Danujdo, DAMPAK ENDOMETRIOSIS PADA KUALITAS HIDUP PEREMPUAN. 2007.

[10] F. Parazzini, P. Viganò, M. Candiani, and L. Fedele, "Diet and endometriosis risk: A literature review," Reprod. Biomed. Online, vol. 26, no. 4, pp. 323-336, 2013, doi: 10.1016/j.rbmo.2012.12.011.

[11] F. Parazzini et al., "Selected food intake and risk of endometriosis," Hum. Reprod., vol. 19, no. 8, pp. 1755-1759, 2004, doi: 10.1093/humrep/deh395.

[12] E. Chavarro et al., "HHS Public Access," vol. 219, no. 2, 2019, doi: 10.1016/j.ajog.2018.05.034.A.

[13] H. R. Harris, A. C. Eke, J. E. Chavarro, and S. A. Missmer, "Fruit and vegetable consumption and risk of endometriosis," Hum. Reprod., vol. 33, no. 4, pp. 715-727, 2018, doi: 10.1093/humrep/dey014.

[14] S. Youseflu, S. Jahanian Sadatmahalleh, A. Mottaghi, and A. Kazemnejad, "The association of food consumption and nutrient intake with endometriosis risk in iranian women: A case-control study," Int. J. Reprod. Biomed., vol. 17, no. 9, pp. 661-670, 2019, doi: 10.18502/ijrm.v17i9.5102.

[15] M. Ashrafi, N. Jahangiri, S. J. Sadatmahalleh, F. Aliani, and M. Akhoond, "Diet and the risk of endometriosis in Iranian women: A case-control study,” Int. J. Fertil. Steril., vol. 14, no. 3, pp. 193-200, 2020, doi: 10.22074/ijfs.2020.44378.

[16] Amanina, "Universitas indonesia pengaruh pemberian strain," 2011

[17] M. A. Mvondo et al., "Soy Intake Since the Prepubertal Age May Contribute to the Pathogenesis of Endometriosis in Adulthood," J. Med. Food, vol. 22, no. 6, pp. 631-638, 2019, doi: 10.1089/jmf.2018.0160.

[18] E. T. Lee and J. W. Wang, Statistical Method for Survival Data Analysis, Third. John Wiley \& Sons, 2003.

[19] M. Kleinbaum, David G. Klein, Survival Analysis. A self-A self-Learning text. 2012.

[20] L. S. Hosmer D.W., Applied Survival Analysis Regression Modeling of Time to Event Data. 1999 
